\title{
Gender and Youth Entrepreneurial Potential: Evidence from the United Arab Emirates
}

\author{
Rachid Zeffane ${ }^{1}$ \\ ${ }^{1}$ Department of Management, Marketing and Public Administration, College of Business Administration, \\ University of Sharjah, United Arab Emirates \\ Correspondence: Rachid Zeffane, Department of Management, Marketing and Public Administration, College of \\ Business Administration, University of Sharjah, P. O. 27272, Sharjah, United Arab Emirates. Tel: \\ 971-6-505-3557.E-mail: zeffaner@sharjah.ac.ae
}

Received: November 19, 2012 Accepted: December 4, $2012 \quad$ Online Published: December 20, 2012

doi:10.5539/ijbm.v8n1p60

URL: http://dx.doi.org/10.5539/ijbm.v8n1p60

\begin{abstract}
The study of entrepreneurship and its linkages to personal traits has been the subject of much interest and research debate in recent years. In particular, much research has been devoted to the examination of youth entrepreneurial potentials and how they might be enhanced. In all this, gender has been a contentious issue, for opinions on whether or not the potential to become an entrepreneur is gender-driven have been rather mixed and certainly not one-sided. This paper is an attempt to contribute to this debate by adding further empirical evidence from the middle-east/gulf region. It draws on a sample of 503 students enrolled in business courses at a University in the United Arab Emirates. Statistical analysis strongly revealed that there were no differences on the overall entrepreneurial potentials between males and females. However, the only item of entrepreneurial potential on which the two groups differed was their predisposition to risk taking. Consistent with previous research, females were less disposed to taking risk. Overall, our findings on entrepreneurial potentials defeat the commonly held stereotypical assumptions that females in middle-east countries may be less averse to entrepreneurial activities than males. Implications for future and research and practice are discussed.
\end{abstract}

Keywords: entrepreneurial potential, risk taking, youth entrepreneurship, gender, United Arab Emirates, Middle-East

\section{Introduction}

With the rising interest in the topic of entrepreneurship and entrepreneurial potential (Christensen, 2004; Segal et al, 2005; Bjandari, 2006; Ghulam et al, 2006; Florin et al, 2007, Harris \& Gibson, 2008; Hessels et al, 2008; Krueger, 2009; Shinnar et al, 2009; Mitchelmore \& Rowley 2010), the issue of gender has attracted a considerable amount of research, generating much speculations on differences between male and female potentials to become entrepreneurs (Mueller, 2004).

This interest has been propelled by strong concerns by governments and policy makers around the world to stimulate entrepreneurship and entrepreneurial drives amongst the youth population, seen as a primary driver for economic growth and development (Bonnett \& Furnham, 1991; Hessels et al, 2008). The main assumption is that young adults with high entrepreneurial potential (EP) are more likely to start a business than are those with lower entrepreneurial potential (Bowman, 1986; Bonnett \& Furnham, 1991; Shinnar et al, 2009).

Although current trends and projections indicate that women will play an increasingly important role in the entrepreneurship, it is not clear whether or not they differ from males in their potentials and the likelihood of their intentions. A common stereotypical assumption is that entrepreneurs are perceived to have predominantly masculine characteristics.

In this study, we attempt to contribute to the research debate and fill the above gap. We focus on gender differences in entrepreneurial potential (EP) as a measure of individual capability and desire to become an entrepreneur, (Krueger \& Brazeal, 1994). We draw on a sample of 503 students enrolled in business courses at a University in the United Arab Emirates. The choice of students as a target sample is appropriate for this kind of study, as future entrepreneurs are more likely to be captured in amongst the population of students, particularly "business" students. This further justified by the fact that youth entrepreneurship programs are often geared to capture the interest of the student populations as a primary target. The validity of student samples for 
entrepreneurial inquiries has been justified in previous research (Bowman, 1986; Koh, H.C, 1996) and the more recent research has been able to draw useful conclusions from such target samples (McClelland, 1965, 1965a; Yi, 2002; Bjandari, 2006; Harris et al, 2008; El Harbi et al, 2009; Grubuz and Aykol, 2009; Zahariah et al, 2010). Previous research has also shown that students are reliable proxis for the purpose of research on potential entrepreneurs. In that perspective, several studies have shown that business students, in particular, are useful and reliable sources in investigating the potentials and profiles of future entrepreneurs in various countries (Koh, 1996; Kourilskva, \& Walstad, 1998; Freeman \& Bordia, 2001; Yi, 2002; Veciano et al, 2005; Zha et al, 2006; Gupta et al, 2008, 2009; Kickul et al, 2010; Nguyen et al, 2010; Zahariah et al, 2010, Yordanova. and Tarrazon, 2010; Arora et al, 2011; Rozell et al, 2011, Houston et al, 2012; Shinnar et al, 2012; Strobl et al, 2012).

\section{Current State of Research Knowledge}

Entrepreneurial potential is recognized as an important precursor to entrepreneurial events or activities (Krueger \& Brazeal 1994). The concept of entrepreneurial potential (EP) refers to the basis capacity and desire of individuals to become entrepreneurs (Krueger \& Brazeal 1994). Individuals with the potential to become entrepreneurs perceive themselves as capable and psychologically equipped to face the challenges of entrepreneurship. In other words, individuals who have capabilities and desire to become entrepreneurs are also more inclined to start a business and indeed become "potential entrepreneurs". An individual with greater entrepreneurial potential (EP) is a person who bears risks, works under uncertainty, combines and manages capital, innovates on all fronts on regular basis, and is motivated by business results (Krueger \& Brazeal, 1994; Sahay \& Rai, 2004). Lumpkin \& Dess (1996) further clarified the definitional issue in entrepreneurship in their 1996 seminal work by making a distinction between entrepreneurship and entrepreneurial potential. They suggested that an entrepreneurial potential (EP) represents entrepreneurial processes that address the question of the willingness and likelihood to undertaken new ventures. These processes include innovativeness, and risk taking. In essence this concept helps us understand the level of necessary pre-conditions that relate to the potential success of future entrepreneurial actions (Lumpkin \& Dess, 1996; Krueger 2009).

While some variation exists in the nature and number of personal facets which can be ascribed to the potential entrepreneur, previous research have commonly included such characteristics as, creativity and innovativeness, leadership capabilities, risk taking, and growth orientation, (Macke and Markley 2003; Thompson 2004, Guerrero et al, 2008; Thomas \& Mueller, 2000; Mueller \& Thomas, 2001). While such characteristics are not necessarily predictors of future entrepreneurial activity in themselves, they are indicative of interest and ability to successfully pursue entrepreneurial opportunities, and as such are important factors in identifying potential future entrepreneurs (Krueger 2009).

It is not clear whether or not there are dominant differences between men and women in this regard. While some studies point at significant gender differences (Mueller, 2004; Asos et al, 2007; El Harbi, et al, 2009; Díaz-García \& Jiménez-Moreno, 2010; Yordanova. \& Tarrazon, 2010; Shinnar et al, 2012), other negate any gender-related differences (Kourilskva, \& Walstadb, 1998; Veciano et al, 2005; Wilson et al, 2007; Maxfield et $\mathrm{al}, 2010$ ). Nevertheless, the more recent studies focusing on female entrepreneurship in the Middle East reveal that a growing number of female graduates are showing increasing interest in entrepreneurial activities (see for example Madichie and Gallant, 2012).

Kourilskva and Walstad (1998) scrutinized a national sample of female and male high school students concerning their entrepreneurship knowledge and attitude in the United States. They focused on whether or not there are any significant gender differences in these areas. Their results revealed that there were many similarities between females and males with respect to their knowledge of and opinions about entrepreneurship. Drawing on the Nordic data of the Global Entrepreneurial Monitor, Asos et al (2007) found significant gender differences in entrepreneurship which included "nascent", "latent" as well as "infant" entrepreneurship. In a tri-national study, Gupta and his colleagues examined the role of socially constructed gender stereotypes and their influence on men and women's entrepreneurial intentions. They found that men and women did not differ in their entrepreneurial intentions (Gupta et al, 2008, 2009).

In contrast, some studies have shown the existence of significant differences in the rate of new business creation between men and women. Specifically, they refer to women as being much less likely to be involved in entrepreneurship than men worldwide (see for example Minniti and Nardone, 2007). Lending some support to this claim, in a study of Bulgarian university students, Yordanova and Tarrazon (2010) found and argued that women tend to have lower entrepreneurial intentions than men.

Drawing on a sample of over 5,000 middle and high school students, Kickul and her colleagues examined the reasons behind the significant gender gaps observed in entrepreneurial interest among adolescents. Their 
findings revealed significant differences between boys and girls. In particular, their data indicated that that self-efficacy seemed to have a stronger effect on entrepreneurial interest for girls than for boys (Kickul et al, 2010). Drawing on a sample of students from a Malaysian University, Zaidatol and Afsaneh (2009) found significant difference between male and female students on entrepreneurial intention where the male students obtained higher mean score.

In a more recent study, Shinnar and her colleagues examined how culture and gender shape entrepreneurial perceptions incorporating perceptions of gender role differences. They tested for gender differences in the way university students in three nations perceive barriers to entrepreneurship and whether gender has a moderating effect on these as well as entrepreneurial intentions across the three nations. Their findings revealed significant gender differences in barrier perceptions. However, they admitted and stressed that this gap was not consistent across cultures (Shinnar et al, 2012). In agreement with this, Strobl and her colleagues drew on a survey of university students and found that male students showed more positive attitudes towards entrepreneurship and much more concrete entrepreneurial intentions (Strobl et al, 2012).

Even some of the recent studies that have focused on youth in the contexts similar to our (i.e. Middle-East/Arab context) have argued in favor of gender differences. For instance, I a study of entrepreneurial intentions among students in Tunisia, El Harbi and her colleagues found greater entrepreneurial intentions amongst males (El Harbi et al, 2009).

\section{Research Questions}

Stemming from the above arguments and the literature to-date, it is unclear whether or not male and female youth differ on their entrepreneurial potentials. It is also unclear, whether or not (and how) they differ on the various characteristics of entrepreneurial potential. Further, since our study is conducted in the middle-east context, it is not clear whether the commonly stereotyped gender roles are present in relation to the potentials of males and females to become entrepreneurs. This leads use to the following research questions:

- $\quad$ Do males and females differ in their entrepreneurial potentials?

- $\quad$ Are any of the entrepreneurial characteristics more predominant in a given gender group?

- Does the stereotypical assumption of greater entrepreneurial potential (and orientation) amongst young males in the middle-eastern countries hold true when we consider youth (business students) in the present context?

\section{Sample and Method}

The data for this study was collected by way of a survey instrument distributed to a sample of students attending business courses in a University in the United Arab Emirates. The choice of students as a target sample is appropriate for this kind of study, as future entrepreneurs are more likely to be captured in amongst the population of students, particularly "business" students. This is further justified by the fact that youth entrepreneurship programs are often geared to capture the interest of the student populations as a primary target. The validity of student samples for research inquiries on entrepreneurship has been strongly justified in previous research (Bowman, 1986; Koh, H.C. 1996) and the more recent research has been able to draw useful conclusions from such target samples (see for example Yi, 2002; Harris et al, 2008; Grubuz and Aykol, 2009; Zahariah et al, 2010).

To ascertain the clarity of the range of item-questions, the questionnaire instrument was piloted randomly prior to final delivery. The questionnaire was entirely in English as the target population of students were in programs/majors delivered entirely in English. It used scales and item-questions borrowed from previous research (see measures section below).

The questionnaire was delivered to students taking upper level courses in business studies. The target sample was based on a necessary representation of the cross-section of students pursuing courses in the College of Business, in terms of their discipline/major, level of study and gender.

The questionnaire was distributed in class-time (at the end of class) and participation in the survey was purely voluntary. In compliance with the university standard code of ethics, a standard protocol for questionnaire distribution was observed, ensuring each respondent the preservation of confidentiality in all responses to the survey that they would make. They were given the option to complete the questionnaire there and then (at the end of their class) and return it to their instructor, or to complete it in their own time and return it to the researchers through their faculty mail-tray. Class instructors (survey facilitators) delivering the questionnaire in their classes were briefed of these conditions by the researchers. In addition to this, survey facilitators were 
required to read out certain statements to the survey participants highlighting the objective of the survey, ensuring respondents' confidentiality, time required to complete the survey, and students' voluntary participation in the survey. The class instructors were specifically requested to distribute the questionnaires during the class times and at the end, while the survey facilitators (i.e. the researchers) personally collected the completed questionnaires.

A total of 700 questionnaires were printed and distributed. A total of 503 students participated in the study by completing the questionnaire, for a $72 \%$ response rate. Table 1 shows the sample distribution by gender and country of current nationality. $\mathbf{5 9 \%}$ of respondents were female, against $\mathbf{4 1 \%}$ males. This distribution is a normal distribution in the UAE University in which the study took place as more females attend business courses by comparison to male students. This distribution is also reflective of the fact that relatively more Muslim females students are constrained to remain within Muslim countries (such as the UAE) to pursue higher education , by comparison to males students who have more of a free choice on the country of higher education. In other words, females are less likely to travel overseas, beyond the confines of Muslim regional boundaries, whereas male students are not constrained as much, in that sense. The respondents were from 38 different nationalities. Details of the distribution by gender and country of current nationality are shown in Appendix 1 . Table 1 shows the sample distribution by gender and nationality, by regions. The age distribution of respondents ranges from 16 to 28 , with a mean age of 20 .

Table 1 . Sample distribution by gender and region of nationality

\begin{tabular}{|c|c|c|c|c|}
\hline & & \multicolumn{2}{|c|}{ Gender } & \multirow[t]{2}{*}{ Total } \\
\hline & & Females & Males & \\
\hline \multirow{8}{*}{$\begin{array}{c}\text { Nationality by } \\
\text { Area }\end{array}$} & GCC (Gulf Cooperation & 173 & 117 & 200 \\
\hline & Council) countries & $(59.7 \%)$ & $(40.3 \%)$ & 290 \\
\hline & Other Middle East Countries & $\begin{array}{c}74 \\
(48.7 \%)\end{array}$ & $\begin{array}{c}78 \\
(51.3 \%)\end{array}$ & 152 \\
\hline & Africa & $\begin{array}{c}31 \\
(88.6 \%)\end{array}$ & $\begin{array}{c}4 \\
(11.4 \%)\end{array}$ & 35 \\
\hline & Asia & $\begin{array}{c}10 \\
(62.5 \%)\end{array}$ & $\begin{array}{c}6 \\
(37.5 \%)\end{array}$ & 16 \\
\hline & Europe & $\begin{array}{c}3 \\
(100.0 \%)\end{array}$ & $\begin{array}{c}0 \\
(.0 \%)\end{array}$ & 3 \\
\hline & North America & $\begin{array}{c}4 \\
(62.5 \%)\end{array}$ & $\begin{array}{c}3 \\
(37.5 \%)\end{array}$ & 7 \\
\hline & Total & $\begin{array}{c}295 \\
(58.6 \%)\end{array}$ & $\begin{array}{c}208 \\
(41.4 \%)\end{array}$ & 503 \\
\hline
\end{tabular}

\section{Measures}

The concept of entrepreneurial potential (EP) refers to the basis capacity and desire of individuals to become entrepreneurs (Krueger and Brazeal 1994). The measure used in this study was inspired from Krueger and Brazeal (1994). It consists of seven item statements tapping aspects of entrepreneurship which include: business intentions, perceived leadership capabilities, competitiveness, innovativeness, growth needs, self-belief in financial management skills and disposition to risk taking. The scale adopted was a five-point Likert scale denoting the degree of agreement -disagreement with each of seven statements. To test for reliability, we subjected these seven items to confirmatory factor analysis. We also checked for their robustness Alpha Cronbach tests. Factorial and scale reliability (Alpha Cronbach) analysis revealed that these items held consistently together to produce a robust measure of entrepreneurship potential (see Table 2)

Gender was measured as a nominal variable with females scoring "1" and males scoring "2". For the purpose of statistical analysis, we treated it as a dummy variable. 
Table 2. Entrepreneurial potential: results of confirmatory factor analysis and reliability tests (rotated component matrix)

Entrepreneurial Intention : I often think of starting or building a

business

Perceived Leadership capabilities : I believe I have good leadership

skills and can be an effective leader

Competitiveness : I am competitive and welcome/enjoy activities that

ask me to compete with others

Innovation : I am innovative and I am able to find solutions to my daily

challenges and problems

Growth needs : I am a hard working person and always try my best to

succeed

Self-belief in financial management skills : I am very good at managing money

Disposition to risk taking : I don't mind taking risk

Cronbach Alpha

Extraction Method: Principal Component Analysis. Rotation Method: Varimax with Kaiser Normalization.

\section{Analysis and Results}

We first explored the relationships amongst the main variables, including the scale items of entrepreneurial potential and gender. These are shown in Table 3.

Table 3. Inter-correlations matrix

\begin{tabular}{|c|c|c|c|c|c|c|c|c|c|}
\hline & & 1 & 2 & 3 & 4 & 5 & 6 & 7 & 8 \\
\hline \multicolumn{10}{|l|}{1 - I often think } \\
\hline \multicolumn{10}{|l|}{ of starting or } \\
\hline \multicolumn{10}{|l|}{ building a } \\
\hline \multicolumn{10}{|l|}{ business } \\
\hline \multicolumn{10}{|l|}{2 - I believe I } \\
\hline \multicolumn{10}{|l|}{ have good } \\
\hline \multicolumn{10}{|l|}{ leadership } \\
\hline \multicolumn{10}{|l|}{ skills and can } \\
\hline \multicolumn{10}{|l|}{ be an effective } \\
\hline \multicolumn{10}{|l|}{ leader } \\
\hline & $\begin{array}{c}\text { Sig. } \\
\text { (2-tailed) }\end{array}$ & .000 & & & & & & & \\
\hline 3 - I am & Pearson & & & & & & & & \\
\hline competitive and & Correlation & & & & & & & & \\
\hline welcome/enjoy & & $265(* *)$ & $474(* *)$ & & & & & & \\
\hline \multicolumn{10}{|l|}{ activities that } \\
\hline \multicolumn{10}{|l|}{ ask me to } \\
\hline compete with & & & & & & & & & \\
\hline
\end{tabular}




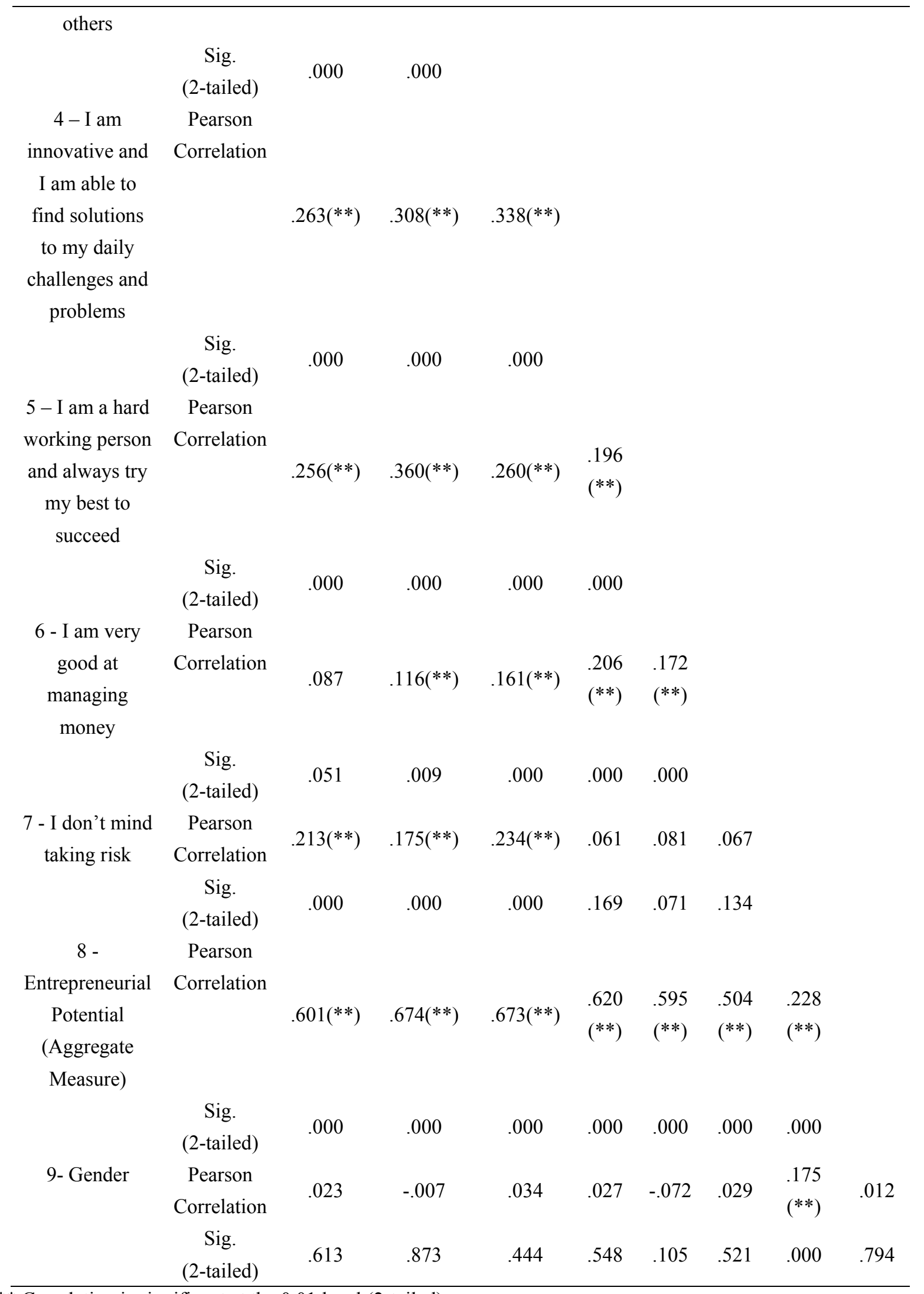

** Correlation is significant at the 0.01 level (2-tailed). 
Overall, these results confirm strong association (or convergence) amongst the characteristics of entrepreneurial potential. The only association that was out of line with the rest was the item denoting "disposition to risk taking". It did not correlate significantly with three of the scale-items. However, this may be explained by the fact that gender also did not relate any of the entrepreneurial potential characteristics, except for "risk taking". Consistent with this, the data shows there was no significant relationship between gender and entrepreneurial potential (overall), except for the characteristic of risk taking where males seem to be more accepting of risk.

To further explore gender differences, we subjected the data to analysis of variance, where gender was introduced as a dummy variable. The results of this analysis are shown in Table 4 (the mean scores used for this analysis are shown in Appendix 2).

Table 4. Analysis of variance

\begin{tabular}{|c|c|c|c|c|c|}
\hline & & $\begin{array}{l}\text { Degrees of } \\
\text { Freedom }\end{array}$ & Mean Square & $\mathrm{F}$ & Sig. \\
\hline \multirow[t]{3}{*}{$\begin{array}{l}\text { I often think of starting or } \\
\text { building a business }\end{array}$} & Between Groups & 1 & .325 & .256 & .613 \\
\hline & Within Groups & 501 & 1.269 & & \\
\hline & Total & 502 & & & \\
\hline \multicolumn{6}{|l|}{ I believe I have good } \\
\hline \multirow{3}{*}{$\begin{array}{l}\text { leadership skills and can be } \\
\text { an effective leader }\end{array}$} & Between Groups & 1 & .024 & .026 & .873 \\
\hline & Within Groups & 501 & .940 & & \\
\hline & Total & 502 & & & \\
\hline \multirow{3}{*}{$\begin{array}{c}\text { I am competitive and } \\
\text { welcome/enjoy activities } \\
\text { that ask me to compete } \\
\text { with others }\end{array}$} & Between Groups & 1 & .599 & .586 & .444 \\
\hline & Within Groups & 501 & 1.022 & & \\
\hline & Total & 502 & & & \\
\hline \multicolumn{6}{|l|}{ I am innovative and I am } \\
\hline \multirow{3}{*}{$\begin{array}{c}\text { able to find solutions to my } \\
\text { daily challenges and } \\
\text { problems }\end{array}$} & Between Groups & 1 & .342 & .362 & .548 \\
\hline & Within Groups & 501 & .945 & & \\
\hline & Total & 502 & & & \\
\hline \multirow{4}{*}{$\begin{array}{l}\text { I am a hard working person } \\
\text { and always try my best to } \\
\text { succeed }\end{array}$} & Between Groups & 1 & 2.356 & 2.639 & .105 \\
\hline & Within Groups & 501 & .893 & & \\
\hline & Total & 502 & & & \\
\hline & Between Groups & 1 & .554 & .413 & .521 \\
\hline
\end{tabular}


managing money

$\begin{array}{cll}\text { Within Groups } & 501 & 1.341 \\ \text { Total } & 502 & \end{array}$

$\begin{array}{cccccc}\text { I don't mind taking risk } & \begin{array}{c}\text { Between Groups } \\ \text { Within Groups }\end{array} & 501 & 20.966 & 15.782 & .000 \\ & \text { Total } & 502 & 1.328 & & \\ \text { Entrepreneurial Potential } & \text { Between Groups } & 1 & .966 & .068 & .794 \\ \begin{array}{ccc}\text { (Aggregate Measure) } \\ \end{array} & \text { Within Groups } & 501 & 14.150 \\ & \text { Total } & 502 & & \\ \end{array}$

These results confirm the above correlation findings and show no significant differences in entrepreneurial potential between males and females. The only significant difference is that relating to risk taking.

\section{Conclusions and Implications}

Despite the increasing interest in researching female entrepreneurship, little is known about gender differences in pre-venture process. The purpose of this study was to provide a conceptual framework for understanding gender differences in entrepreneurial potentials. We explored gender effects on entrepreneurial potentials and identify factors that may account for the gender gap in entrepreneurial intentions in a sample of university students in the United Arab Emirates. Our findings strongly suggest that youth entrepreneurship is not gender-bias and that both men and women reported similar potentials. This lends support to a number of studies (Kourilskva, \& Walstad, 1998; Veciano et al, 2005; Wilson et al, 2007; Maxfield et al, 2010), but does not support the findings of studies conducted in similar cultural contexts to ours (see for example El Harbi et al, 2009; Zaidatol \& Afsaneh, 2009).

The only characteristic that was different across gender groups was the predisposition to "risk taking" This does lend tome support to previous research. However, since this characteristic was the result of responses to a single item on the entrepreneurial potential scale, it is hard to uphold its validity across the board. Our findings on differences related to greater male predisposition to risk taking lend support to early research on gender and risk taking (see for example Harris et al, 2006). However, they do not support findings from the more recent research (see for example Maxfield et al, 2010).

Unfortunately, there remains an underlying societal stereotypes associating entrepreneurship with masculine characteristics. Although entrepreneurship has traditionally been perceived to be a masculine-stereotyped domain, our findings suggest that this no longer holds true, even in the Middle East context. This suggests that common gender stereotypes have been nullified. Males do not inherently hold more entrepreneurial potentials than females (Madichie and Gallant, 2012).

From the research implications viewpoint, our study reveals that the potential to become an entrepreneur is not gender-related. Despite the selective focus (i.e., students in the gulf/middle east context), the above findings add to the current state of knowledge on the need to avert stereotyping in ventures and activities aimed at encouraging both males and females to undertake entrepreneurial activities. However, these findings need to be taken with some caution as the research platform is not sufficiently broad to warrant full generalization regarding attitudes towards entrepreneurship I the Middle East as a whole. Future research may consider re-examining the gender issue in the context of a much larger cross-national comparative study involving countries such as Qatar, Saudi Arabia, Bahrain, Oman, and so on. Gender-related studies n these latter countries remain lacking. The main practical implication that stems from our findings is that policy makers should involve more females in their plans to enhance entrepreneurial activities. This is already occurring in many countries in the Gulf. However, efforts and intents in the region still remain in their infancy by comparison to policies already adopted in the more advanced Western countries. 


\section{Acknowledgment}

The author would like to thank all the business students at the University of Sharjah (UAE) who have kindly volunteered their time and contributed to this research by completing and returning the questionnaire.

\section{References}

Arora, S., Singhai, M., \& Patel, R. (2011). Gender \& Education Determinants of Individualism-Collectivism: A Study of Future Managers. Indian Journal of Industrial Relations, 47(2), 321-328.

Asos, Gry, Agnete, Bruyneel, Stijn, \& Carter, S. (2007). Gender Differences in Entrepreneurial Inentions and Business Start up activities. Frontiers of Entrepreneurship Research, 27(8), 237-246.

Bjandari, \& Narendra, C. (2006). Intention for Entrepreneurship among Students in India. Journal of Entrepreneurship, 15(2), 169-179. http://dx.doi.org/10.1177/097135570601500204

Bonnett, C., \& Furnham, A. (1991). Who wants to be an entrepreneur? A study of adolescents interested in a young enterprise scheme. Journal of Economic Psychology, 12(3), 465-478. http://dx.doi.org/10.1016/0167-4870(91)90027-Q

Bowman, \& Nancy, B. (1986). Validation of personality index: Comparative psychological characteristics analysis of female entrepreneurs, managers, entrepreneurship students and business students. In Ronstadt et al. Frontiers of entrepreneurship research. Wellesley, Mass: Babson College.

Caird, S. (1991). Testing enterprise tendency in occupational groups. British Journal of Management, 12(2), 177-186. http://dx.doi.org/10.1111/j.1467-8551.1991.tb00025.x

Christensen, \& Karina, S. (2004). A Classification of the corporate entrepreneurship umbrella: labels and perspectives. International Journal of Management and Enterprise Development, 1(4), 301-315. http://dx.doi.org/10.1504/IJMED.2004.004635

Díaz-García, Maria, \& Jiménez-Moreno, J. (2010). Entrepreneurial intention: the role of gender. International Entrepreneurship and Management Journal, 6(3), 261-283. http://dx.doi.org/10.1007/s11365-008-0103-2

El Harbi, Sana, Alister Anderson, \& Naima, M. (2009). The Attractiveness of Entrepreneurship for Females and Males in a Developing Arab Muslim Country: Tunisia. International Business Research, 2(3), 46-53.

Florin, Juan, Ranjan, Karri, \& Nancy, R. (2007). Fostering Entrepreneurial Drive in Business Education: An Attitudinal Approach. Journal of Management Education, 31(1), 17-42. http://dx.doi.org/10.1177/1052562905282023

Freeman, Mark, A., \& Bordia, Prashant. (2001). Assessing alternative models of individualism and collectivism: a confirmatory factor analysis. European Journal of Personality, 15(2), 105-121. http://dx.doi.org/10.1002/per.398

Ghulam, N., Rick, H., \& Andreas, W. (2006). Graduate career-making and business start up: a literature review. Education and Training, 48(5), 373-385. http://dx.doi.org/10.1108/00400910610677072

Grubuz, G., \& Aykol, S. (2009). Entrepreneurial management, entrepreneurial orientation and Turkish small firm growth. Management Research News, 32(4), 321-336. http://dx.doi.org/10.1108/01409170910944281

Guerrero, M., Rialp, J., \& Urbano, D. (2008). The impact of desirability and feasibility on entrepreneurial intentions: A structural equation model. International Entrepreneurship and Management Journal, 4(1), 35-50. http://dx.doi.org/10.1007/s11365-006-0032-x

Gupta, Vishal, K., Turban, Daniel, B., Bhawe, \& Nachiket, M. (2008). The effect of gender stereotype activation on entrepreneurial intentions. Journal of Applied Psychology, 93(5), 1053-1061. http://dx.doi.org/10.1037/0021-9010.93.5.1053

Gupta, Vishal, K., Daniel, B., Turban, S., Arzu, W., \& Arijit, S. (2009). The Role of Gender Stereotypes in Perceptions of Entrepreneurs and Intentions to Become an Entrepreneur. Entrepreneurship Theory and Practice, 33(2), 397-417. http://dx.doi.org/10.1111/j.1540-6520.2009.00296.x

Harris, Christine, R., Michael, J., \& Dale, G. (2006) Gender Differences in Risk Assessment: Why do Women take Fewer Risks. Judgment and Decision Making, 1(1), 48-63. http://dx.doi.org/10.1108/00400910810909036

Harris, Michael, L., Shannan, G., \& Gibson. (2008). Examining the Entrepreneurial attitudes of US business students. Education and Training, 50(7), 368-381. http://dx.doi.org/10.1007/s11187-008-9134-x 
Hessels, Jolanda, van Gelderen, Marco, \& Thurik, R. (2008). Entrepreneurial aspirations, motivations, and their drivers. Small Business Economics, 31(3), 323-339.

Houston, John, M., Edge, Hoyt et al. (2012). Competitiveness and Individualism-Collectivism in Bali and the U.S. North American Journal of Psychology; 14(1), 163-173.

Kickul, Jill, Fiona, Wilson et al. (2008). Are misalignments of perceptions and self-efficacy causing gender gaps in entrepreneurial intentions among our nation's teens? Journal of Small Business and Enterprise Development, 15(2), 321-335. http://dx.doi.org/10.1108/14626000810871709

Koh, H. C. (1996). Testing hypotheses of entrepreneurial characteristics: A study of Hong Kong MBA students. Journal of Managerial Psychology, 11(3), 12-25. http://dx.doi.org/10.1108/02683949610113566

Kourilskva, Marilyn, \& William, B. (1998). Entrepreneurship and female youth: knowledge, attitudes, gender differences, and educational practices, Journal of Business Venturing, 13(1), 77-88. http://dx.doi.org/10.1016/S0883-9026(97)00032-3

Krueger, N. F. (2009). Entrepreneurial Intentions are Dead: Long Live Entrepreneurial Intentions. In A. L. Carsrud and M. Brannback (eds.), Understanding the Entrepreneurial Mind, Springer, New York, pp. 51-72. http://dx.doi.org/10.1007/978-1-4419-0443-0_4

Lumpkin, G. T., \& Dess, G. G. (1996). Clarifying the entrepreneurial orientation construct and linking it to performance. Academy of Management Review, 21(1), 135-172.

Macke, D., \& Markley, D. (2003). Entrepreneur Self-test, The Center for Rural Entrepreneurship. Retrieved from http://www.energizingentrepreneurs.org/content/chapter_1/tools/1_000031.pdf

Madichie, Nnamdi, \& Monica, G. (2012). Broken silence: A commentary on women entrepreneurship in the United Arab Emirates. Entrepreneurship and Innovation, 13(2), 81-92. http://dx.doi.org/10.5367/ijei.2012.0071

Maxfield, Sylvia, Mary, S., Vipin, G., \& Susan, H. (2010). Gender and risk: women, risk taking and risk aversion. Gender in Management: An International Journal, 25(7), 586-604. http://dx.doi.org/10.1108/17542411011081383

McClelland, D. C. (1965). Achievement and entrepreneurship: a longitudinal study. Journal of Personality and Social Psychology, 1(4), 389-92. http://dx.doi.org/10.1037/h0021956

McClelland, D. C. (1965a). Achievement and entrepreneurship: A longitudinal study. Journal of personality and Social Psychology, 1(1), 389-392. http://dx.doi.org/10.1037/h0021956

Minniti, Maria, \& Carlo, N. (2007) Being in Soemone Else Shoes: the Role of Gender in Nascent $\begin{array}{llll}\text { Entrepreneurship. Small } & \text { Business 223-238. }\end{array}$ http://dx.doi.org/10.1007/s11187-006-9017-y

Mitchelmore, Siwan, \& Rowley, J. (2010) Entrepreneurial competencies: a literature review and development agenda. International Journal of Entrepreneurial Behavior and Research, 16(2), 92-111. http://dx.doi.org/10.1108/13552551011026995

Moore, \& Carol, F. (1986). Understanding entrepreneurial behavior. In J.A. Pearce and R.B. Robinson, editors, Academy of Management best papers, Forty-Sixth Annual Meeting, Academy of Management, Chicago.

Mueller, S. L., \& Thomas, A. S. (2001). Culture and entrepreneurial potential: A nine country study of locus of control and innovativeness. Journal of Business Venturing, 16(1), 51-75. http://dx.doi.org/10.1016/S0883-9026(99)00039-7

Mueller, \& Stephen, L. (2004). Gender Gaps in Potential for Entrepreneurship Across Countries and Cultures. Journal of Developmental Entrepreneurship, 9(3), 199-220.

Nguyen, Hannah-Hanh, D., Huy, L., \& Boles, T. (2010). Individualism-Collectivism and Co-operation: A Cross Society and Cross-Level Examination. Negotiation \& Conflict Management Research, 3(1), 179-204. http://dx.doi.org/10.1111/j.1750-4716.2010.00057.x

Rozell, Elizabeth, J., Meyer, Kenneth, E., Scroggins, Wesley, A., \& Guo, A. (2011). Perceptions of the Characteristics of Successful Entrepreneurs: An Empirical Study in China. International Journal of Management, 28(4), 60-71.

Sahay, A., \& Rai, S. K. (2004). How entrepreneurial are youth of Varanasi: An empirical study through cyber cafe's. Journal of Services Research, 4(2), 175-203. 
Segal, Gerry, Dan, B., \& Jerry, S. (2005). The Motivation to become and Entrepreneur. International Journal of Entrepreneurial Behavior and Research, 1(1), 42-57. http://dx.doi.org/10.1108/13552550510580834

Shinnar, Rachel, Mark, P., \& Bryan, T. (2009). Entrepreneurship Education: Attitudes Across Campus. Journal of Education for Business, 84(3), 151-160. http://dx.doi.org/10.3200/JOEB.84.3.151-159

Shinnar, Rachel, O., Giacomin, \& Frank, J. (2012). Entrepreneurial Perceptions and Intentions: The Role of Gender and Culture. Entrepreneurship Theory and Practice, 36(3), 465-493. http://dx.doi.org/10.1111/j.1540-6520.2012.00509.x

Strobl, A., Christopher, K., \& Mike, P. (2012). Entrepreneurial attitudes and intentions: assessing gender specific differences. International Journal of Entrepreneurship and Small Business, 15(4), 452-468. http://dx.doi.org/10.1504/IJESB.2012.046475

Thomas, A. S., \& Mueller, S. L. (2000). A case for comparative entrepreneurship: Assessing the relevance of culture. Journal of International Business Studies, 31(2), 287-301. http://dx.doi.org/10.1057/palgrave.jibs.8490906

Thompson, J. L. (2004). The facets of the entrepreneur: Identifying entrepreneurial potential. Management Decision, 42(2), 243-258. http://dx.doi.org/10.1108/00251740410515861

Veciano, Jose, M., Marines, A., \& David, U. (2005). University Students' attitudes towards entrepreneurship : a tri-country study. International Entrepreneurship and Management, 11(2), 165-182. http://dx.doi.org/10.1007/s11365-005-1127-5

Wilson, Fiona, Jill, K., \& Deborah, M. (2007). Gender, Entrepreneurial Self-Efficacy, and Entrepreneurial Career Intentions: Implications for Entrepreneurship Education. Entrepreneurship Theory and Practice, 31(3), 387-406. http://dx.doi.org/10.1111/j.1540-6520.2007.00179.x

Yi, \& Jung, S. (2002). Individualism-Collectivism: A Study of College Students in Four Countries. Journal of the Speech and Theatre Association of Missouri, 32(1), 105- 117.

Yordanova, Desislava, I., \& Maria-Antonia, T. (2010). Gender Differences in Entrepreneurial Intentions: Evidence from Bulgaria. Journal of Developmental Entrepreneurship, 15(3), 245-261. http://dx.doi.org/10.1142/S1084946710001543

Zahariah Mohd Zain, Amalina Mohd Akram, Ghani, \& Erlane, K. (2010). Entrepreneurship Intention Among Malaysian Business Students. Canadian Social Science, 6(3), 34-44.

Zha, Peijia, Walczyk, Jeffrey, Griffith-Ross, Diana, A., Tobacyk, Jerome, J., Walczyk, \& Daniel. F. (2006). The Impact of Culture and Individualism-Collectivism on the Creative Potential and Achievement of American and Chinese Adults. Creativity Research Journal, 18(3), 355-366.

Zaidatol Akmaliah Lope Pihie, \& Afsaneh Bagheri. (2009). Entrepreneurial Intention of University Students: An Analysis of Gender and Ethnic Groups. International Journal of Knowledge, Culture and Change Management, 9(4), 49-60. http://dx.doi.org/10.1207/s15326934crj1803_10

\section{Appendices}

Appendix 1. Sample distribution by gender groups. country of current nationality and regional groupings of nationalities

\begin{tabular}{|c|c|c|c|c|}
\hline \multirow{2}{*}{ Nationality } & \multirow{2}{*}{ Regional Groupings } & \multicolumn{2}{|c|}{ Gender } & \multirow{2}{*}{ Tota } \\
\hline & & Female & Male & \\
\hline UAE & $\begin{array}{c}\text { GCC (Gulf Cooperation } \\
\text { Council) }\end{array}$ & $\begin{array}{c}147 \\
(58.3 \%)\end{array}$ & $\begin{array}{c}105 \\
(41.7 \%)\end{array}$ & 252 \\
\hline Saudi Arabia & $\begin{array}{l}\text { GCC (Gulf Cooperation } \\
\text { Council Countries) }\end{array}$ & $\begin{array}{c}16 \\
(64.0 \%)\end{array}$ & $\begin{array}{c}9 \\
(36.0 \%)\end{array}$ & 25 \\
\hline Syria & $\begin{array}{l}\text { Other Middle East } \\
\text { Countries }\end{array}$ & $\begin{array}{c}4 \\
(20.0 \%)\end{array}$ & $\begin{array}{c}16 \\
(80.0 \%)\end{array}$ & 20 \\
\hline Afghanistan & $\begin{array}{l}\text { Other Middle East } \\
\text { Countries }\end{array}$ & $\begin{array}{c}4 \\
(100.0 \%)\end{array}$ & $\begin{array}{c}0 \\
(.0 \%)\end{array}$ & 4 \\
\hline Yemen & $\begin{array}{c}\text { Other Middle East } \\
\text { Countries }\end{array}$ & $\begin{array}{c}9 \\
(52.9 \%) \\
\end{array}$ & $\begin{array}{c}8 \\
(47.1 \%) \\
\end{array}$ & 17 \\
\hline
\end{tabular}




\begin{tabular}{|c|c|c|c|c|c|}
\hline & Sudan & Africa & $\begin{array}{c}6 \\
(85.7 \%)\end{array}$ & $\begin{array}{c}1 \\
(14.3 \%)\end{array}$ & 7 \\
\hline & Iran & $\begin{array}{c}\text { Other Middle East } \\
\text { Countries }\end{array}$ & $\begin{array}{c}6 \\
(75.0 \%)\end{array}$ & $\begin{array}{c}2 \\
(25.0 \%)\end{array}$ & 8 \\
\hline & Morocco & Africa & $\begin{array}{c}1 \\
(100 \%)\end{array}$ & $\begin{array}{c}0 \\
(.0 \%)\end{array}$ & 1 \\
\hline & Jordan & $\begin{array}{l}\text { Other Middle East } \\
\text { Countries }\end{array}$ & $\begin{array}{c}21 \\
(67.7 \%)\end{array}$ & $\begin{array}{c}10 \\
(32.3 \%)\end{array}$ & 31 \\
\hline & Palestine & $\begin{array}{l}\text { Other Middle East } \\
\text { Countries }\end{array}$ & $\begin{array}{c}17 \\
(42.5 \%)\end{array}$ & $\begin{array}{c}23 \\
(57.5 \%)\end{array}$ & 40 \\
\hline & Nigeria & Africa & $\begin{array}{c}12 \\
(92.3 \%)\end{array}$ & $\begin{array}{c}1 \\
(7.7 \%)\end{array}$ & 13 \\
\hline & Oman & $\begin{array}{l}\text { GCC (Gulf Cooperation } \\
\text { Council Countries) }\end{array}$ & $\begin{array}{c}4 \\
(100.0 \%)\end{array}$ & $\begin{array}{c}0 \\
(.0 \%)\end{array}$ & 4 \\
\hline & Iraq & $\begin{array}{c}\text { Other Middle East } \\
\text { Countries }\end{array}$ & $\begin{array}{c}4 \\
(50.0 \%)\end{array}$ & $\begin{array}{c}4 \\
(50.0 \%)\end{array}$ & 8 \\
\hline & Comoro Island & Africa & $\begin{array}{c}2 \\
(100.0 \%)\end{array}$ & $\begin{array}{c}0 \\
(.0 \%)\end{array}$ & 2 \\
\hline & Egypt & $\begin{array}{c}\text { Other Middle East } \\
\text { Countries }\end{array}$ & $\begin{array}{c}3 \\
(25.0 \%)\end{array}$ & $\begin{array}{c}9 \\
(77.0 \%)\end{array}$ & 12 \\
\hline & Bahrain & $\begin{array}{l}\text { GCC (Gulf Cooperation } \\
\text { Council Countries) }\end{array}$ & $\begin{array}{c}3 \\
(50.0 \%)\end{array}$ & $\begin{array}{c}3 \\
(50.0 \%)\end{array}$ & 6 \\
\hline & Lebanon & $\begin{array}{c}\text { Other Middle East } \\
\text { Countries }\end{array}$ & $\begin{array}{c}6 \\
(50.0 \%)\end{array}$ & $\begin{array}{c}6 \\
(50.0 \%)\end{array}$ & 12 \\
\hline & Libya & Africa & $\begin{array}{c}3 \\
(100.0 \%)\end{array}$ & $\begin{array}{c}0 \\
(.0 \%)\end{array}$ & 3 \\
\hline & India & Asia & $\begin{array}{c}3 \\
(75.0 \%)\end{array}$ & $\begin{array}{c}1 \\
(25.0 \%)\end{array}$ & 4 \\
\hline & USA & North America & $\begin{array}{c}1 \\
(33.3 \%)\end{array}$ & $\begin{array}{c}2 \\
(66.7 \%)\end{array}$ & 3 \\
\hline & Somalia & Africa & $\begin{array}{c}3 \\
(75.0 \%)\end{array}$ & $\begin{array}{c}1 \\
(25.0 \%)\end{array}$ & 4 \\
\hline & Canada & North America & $\begin{array}{c}3 \\
(75.0 \%)\end{array}$ & $\begin{array}{c}1 \\
(25.0 \%)\end{array}$ & 4 \\
\hline & Qatar & $\begin{array}{l}\text { GCC (Gulf Cooperation } \\
\text { Council Countries) }\end{array}$ & $\begin{array}{c}2 \\
(100.0 \%)\end{array}$ & $\begin{array}{c}0 \\
(.0 \%)\end{array}$ & 2 \\
\hline & Denmark & Europe & $\begin{array}{c}1 \\
(100.0 \%)\end{array}$ & $\begin{array}{c}0 \\
(.0 \%)\end{array}$ & 1 \\
\hline & Pakistan & Asia & $\begin{array}{c}5 \\
(83.0 \%)\end{array}$ & $\begin{array}{c}1 \\
(16.7 \%)\end{array}$ & 6 \\
\hline & $\begin{array}{c}\text { United Kingdom of } \\
\text { Britain }\end{array}$ & Europe & $\begin{array}{c}1 \\
(100.0 \%)\end{array}$ & $\begin{array}{c}0 \\
(.0 \%)\end{array}$ & 1 \\
\hline & Kuwait & $\begin{array}{l}\text { GCC (Gulf Cooperation } \\
\text { Council Countries) }\end{array}$ & $\begin{array}{c}1 \\
(100.0 \%)\end{array}$ & $\begin{array}{c}0 \\
(.0 \%)\end{array}$ & 1 \\
\hline & Turkey & Asia & $\begin{array}{c}1 \\
(100.0 \%)\end{array}$ & $\begin{array}{c}0 \\
(.0 \%)\end{array}$ & 1 \\
\hline & France & Europe & $\begin{array}{c}1 \\
(100 \%)\end{array}$ & $\begin{array}{c}0 \\
(.0 \%)\end{array}$ & 1 \\
\hline & Algeria & Africa & $\begin{array}{c}4 \\
(100 \%)\end{array}$ & $\begin{array}{c}0 \\
(.0 \%)\end{array}$ & 4 \\
\hline & Russia & Asia & $\begin{array}{c}1 \\
(33.3 \%)\end{array}$ & $\begin{array}{c}2 \\
(66.7 \%)\end{array}$ & 3 \\
\hline & Bangladesh & Asia & $\begin{array}{c}0 \\
(.0 \%)\end{array}$ & $\begin{array}{c}2 \\
(100.0 \%)\end{array}$ & 2 \\
\hline & Chad & Africa & $\begin{array}{c}0 \\
(.0 \%)\end{array}$ & $\begin{array}{c}1 \\
(100.0 \%)\end{array}$ & 1 \\
\hline Total & & & $\begin{array}{c}295 \\
(58.6 \%)\end{array}$ & $\begin{array}{c}208 \\
(41.4 \%)\end{array}$ & 503 \\
\hline
\end{tabular}


Appendix 2. Comparison of mean distributions

\begin{tabular}{|c|c|c|c|c|c|c|}
\hline & \multicolumn{3}{|c|}{ Males } & \multicolumn{3}{|c|}{ Females } \\
\hline & $\mathrm{N}$ & Mean & $\begin{array}{c}\text { Std. } \\
\text { Deviation } \\
\end{array}$ & $\mathrm{N}$ & Mean & $\begin{array}{c}\text { Std. } \\
\text { Deviation }\end{array}$ \\
\hline $\begin{array}{l}\text { I often think of starting or building } \\
\text { a business }\end{array}$ & 208 & 3.96 & 1.14 & 295 & 3.91 & 1.11 \\
\hline $\begin{array}{l}\text { I believe I have good leadership } \\
\text { skills and can be an effective } \\
\text { leader }\end{array}$ & 208 & 3.80 & .98 & 295 & 3.82 & .96 \\
\hline $\begin{array}{l}\text { I am competitive and } \\
\text { welcome/enjoy activities that ask } \\
\text { me to compete with others }\end{array}$ & 208 & 3.75 & 1.04 & 295 & 3.68 & .99 \\
\hline $\begin{array}{l}\text { I am innovative and I am able to } \\
\text { find solutions to my daily } \\
\text { challenges and problems }\end{array}$ & 208 & 3.85 & .99 & 295 & 3.79 & .96 \\
\hline $\begin{array}{l}\text { I am a hard working person and } \\
\text { always try my best to succeed }\end{array}$ & 208 & 4.00 & 1.09 & 295 & 4.14 & .82 \\
\hline $\begin{array}{l}\text { I am very good at managing } \\
\text { money }\end{array}$ & 208 & 3.39 & 1.08 & 295 & 3.32 & 1.21 \\
\hline I don't mind taking risk & 208 & 3.39 & & 295 & 2.98 & 1.67 \\
\hline $\begin{array}{l}\text { Entrepreneurial } \\
\text { (Aggregate Measure) }\end{array}$ & 208 & 22.75 & 4.02 & 295 & 22.66 & 3.57 \\
\hline Valid N (listwise) & 208 & & & 295 & & \\
\hline
\end{tabular}

